\title{
Targeting land-use change for nitrate- nitrogen load reductions in an agricultural watershed
}

\author{
M.K. Jha, K.E. Schilling, P.W. Gassman, and C.F. Wolter
}

\begin{abstract}
The research was conducted as part of the USDA's Conservation Effects Assessment Project. The objective of the project was to evaluate the environmental effects of land-use changes, with a focus on understanding how the spatial distribution throughout a watershed influences their effectiveness. The Soil and Water Assessment Tool (SWAT) water quality model was applied to the Squaw Creek watershed, which covers 4,730 ha (11,683 ac) of prime agriculture land in southern Iowa. The model was calibrated (2000 to 2004) and validated (1996 to 1999) for overall watershed hydrology and for streamflow and nitrate loadings at the watershed outlet on an annual and monthly basis. Four scenarios for land-use change were evaluated including one scenario consistent with recent land-use changes and three scenarios focused on land-use change on highly erodible land areas, upper basin areas, and floodplain areas. Results for the Squaw Creek watershed suggested that nitrate losses were sensitive to land-use change. If land-use patterns were restored to 1990 conditions, nitrate loads may be reduced $7 \%$ to $47 \%$ in the watershed and subbasins, whereas converting row crops to grass in highly erodible land, upper basin, and floodplain areas would reduce nitrate loads by $47 \%, 16 \%$, and $8 \%$, respectively. These SWAT model simulations can provide guidance on how to begin targeting land-use change for nitrate load reductions in agricultural watersheds.
\end{abstract}

Key words: calibration-Conservation Effects Assessment Project (CEAP)-land-use change-Soil and Water Assessment Tool (SWAT)—watershed modeling

\section{Excessive nitrate-nitrogen (nitrate) loads are a major cause of surface water impair- ment in the United States (USEPA 2003) and contribute to hypoxic conditions in the Gulf of Mexico (Turner and Rabalais} 1994). Public water supplies that utilize surface water intakes are also threatened when nitrate concentrations exceed the US Environmental Protection Agency maximum contaminant level of $10 \mathrm{mg} \mathrm{L}^{-1}$. For example, the City of Des Moines in central Iowa utilizes the Raccoon River for a portion of its water supply, and the river, like many other Midwestern river systems, has been negatively impacted by excessive nitrate loads. A recent assessment indicated that a $48 \%$ reduction in nitrate loads is needed for the river to be in compliance with its total maximum daily load (Schilling et al. 2008b).

Manipulation of land use is one of the most promising practices for achieving nitrate load reductions sufficiently large enough for rivers
Wildlife Refuge in Iowa demonstrated that stream nitrate concentrations were reduced $1.2 \mathrm{mg} \mathrm{L} \mathrm{L}^{-1}$ during reintroduction of native prairie vegetation in $23 \%$ of the watershed over a 10-year monitoring period (Schilling and Spooner 2006). Such field evaluations of changes in land use are generally very difficult to perform at a watershed scale. However, water quality models such as the Soil Water Assessment Tool (SWAT) model (Arnold et al. 1998; Arnold and Forher 2005; Gassman et al. 2007) offer an efficient alternative approach for evaluating the effectiveness of land use or best management practice (BMP) changes to reduce nitrate and other pollutant loads from a watershed. SWAT has been used extensively to evaluate BMP impacts on nutrient loads in streams at a watershed scale and has also been used to evaluate watershed-scale impacts of land-use changes, although primarily just on hydrologic indicators (Gassman et al. 2007). Several recent studies have focused on a targeted evaluation approach of BMP with SWAT (e.g., Schilling and Wolter 2009; Maringanti et al. 2009; White et al. 2009); such strategies are needed to identify areas where pollutant loading rates can be reduced with greater efficiency (Walter et al. 2007). Thus a targeted approach is used in this study for assessing the effects of land-use change for reducing nitrate loss.

This study presents hydrologic and water quality modeling efforts using SWAT for the Squaw Creek watershed to identify locations in the watershed where conversion of annual crops to perennial grassland would have the greatest potential for achieving nitrate load reductions. This watershed was selected because it was the site of a 10-year water quality monitoring project, serving as the control basin for the large-scale landuse changes implemented at the Neal Smith National Wildlife Refuge in adjacent Walnut Creek watershed (Schilling et al. 2006). The Squaw Creek watershed was also a com-

Manoj K. Jha is an assistant professor in the Civil Engineering Department at North Carolina A\&T State University, Greensboro, North Carolina. Keith E. Schilling is a research geologist with the lowa Geological Survey Bureau of lowa Department of Natural Resources, lowa City, lowa. Philip W. Gassman is an associate scientist with the CARD at lowa State University in Ames, lowa. Calvin F. Wolter is a lead geographical information system analyst with the lowa Geological Survey Bureau of lowa Department of Natural Resources, lowa City, lowa. 
ponent of the USDA Cooperative States Research, Education, and Extension Service Conservation Effects Assessment Project assessment study for watersheds representing three distinct landform regions in Iowa (Schilling et al. 2007). The monitoring study results and the modeling findings reported here directly support the goals of the Conservation Effects Assessment Project, which seeks to evaluate the effectiveness of different conservation practices in mitigating water quality problems in a variety of watershed conditions across the United States (Richardson et al. 2008; Duriancik et al. 2008).

The Squaw Creek watershed was designated as a control in the original monitoring study (Schilling and Spooner 2006). However, land-use change occurred in the watershed during the monitoring project, with substantial portions of the basin converted from Conservation Reserve Program (CRP) grasslands to annual row crops. Hence the watershed provides a suitable backdrop to evaluate the effects of past and future land-use change involving perennial vegetation. The designation of Squaw Creek watershed as a control for the region implies that basin characteristics, land use, and management practices are typical of the Western Corn Belt Plains Level III Ecoregion (47), which encompasses most of Iowa (Omernick et al. 1994).

The specific objectives for this study were to (1) calibrate and validate SWAT based on testing with streamflow and nitrate data collected at the outlet of Squaw Creek; (2) simulate scenarios of converting CRP land back to row crops, similar to historical trends that occurred in the watershed during the past two decades; and (3) simulate scenarios of row crop conversion into CRP land to determine the most effective targeting of increased grassland in Squaw Creek and similar watersheds.

\section{Materials and Methods}

Squaw Creek Watershed. Squaw Creek is a third-order stream, draining 4,730 ha $(11,683$ ac) above its confluence with the South Skunk River in Jasper County, Iowa (figure $1)$. The watershed is located in the southern Iowa Drift Plain Landscape Region, an area characterized by steeply rolling hills and well-developed drainage. Soils consist mainly of silty clay loams, silt loams, or clay loams formed in loess and pre-Illinoian till overlying Pennsylvanian Cherokee Group shale, limestone, sandstone, and coal (Schilling

\section{Figure 1}

The Squaw Creek watershed and subbasin delineation for the Soil and Water Assessment Tool modeling.

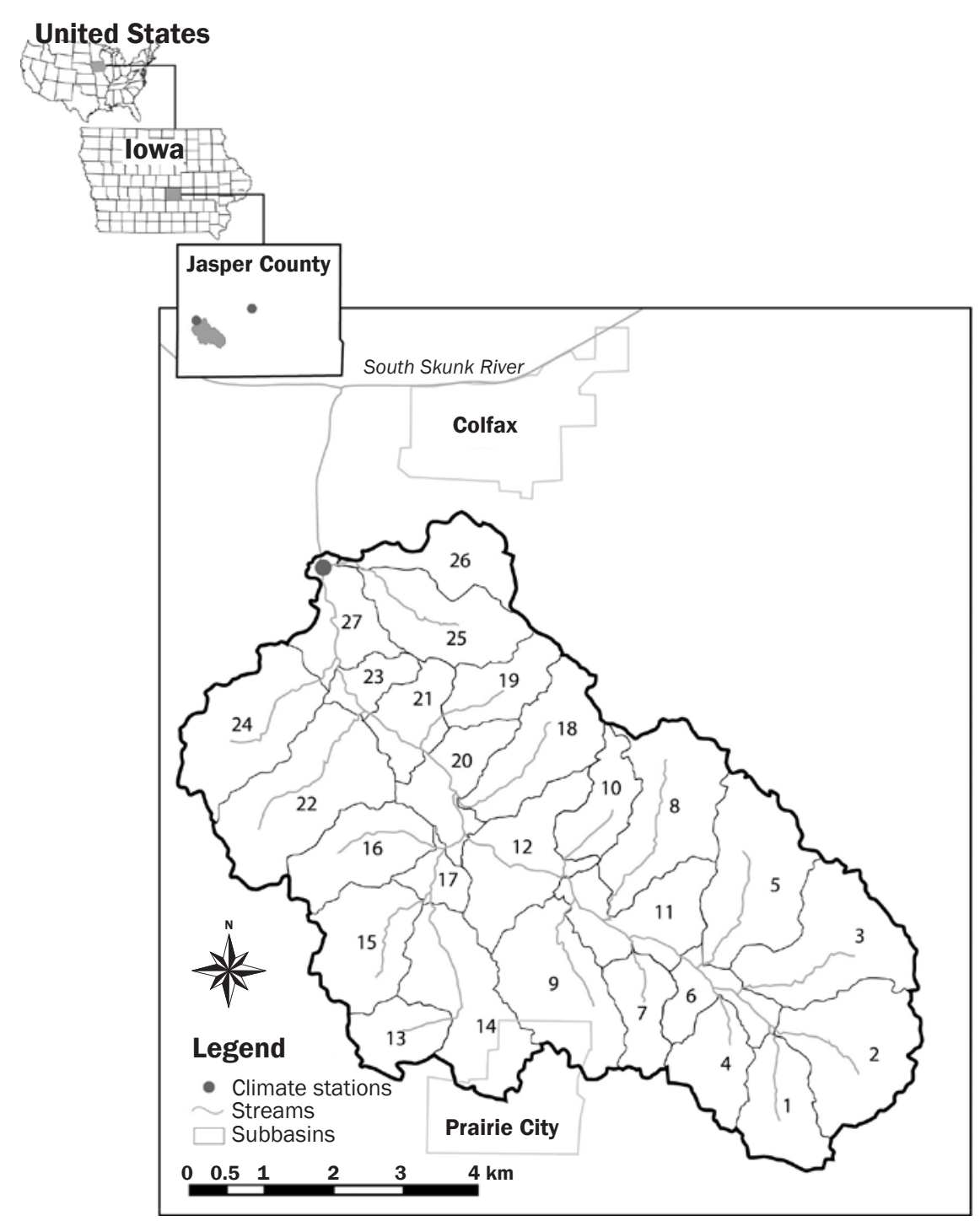

et al. 2006). The study area is in a humid, continental region with average annual precipitation of $750 \mathrm{~mm}$ (29.5 in). As of 2005, land use in Squaw Creek watershed consisted of $75.1 \%$ row crop $(3,535$ ha $[8,735$ ac]), $16.3 \%$ grassland (pasture and CRP 765 ha $[1,890 \mathrm{ac}]), 5.2 \%$ urban (243 ha [600.5 ac]), $1.4 \%$ forest (66 ha [163 ac]) and less than $2 \%$ roads, water, and other unclassified land covers. The proportion of land in row crop increased from $69.8 \%$ to $75.1 \%$ between 1990 to 2005 , along with a corresponding decrease in grassland.

Monitoring Data. As part of the Walnut Creek paired watershed study, discharge was measured daily at a US Geological Survey
(USGS) gaging station located at the Squaw Creek outlet (figure 1). The stage was monitored continuously with bubble-gage sensors and was recorded by a data collection platform at 15-minute intervals. A rating curve was developed to compute stream discharge according to standard USGS methods (Kennedy 1983). Daily mean discharge was compiled as monthly and annual totals in this study for model calibration.

Surface water samples were collected in Squaw Creek watershed on a weekly to bimonthly basis from 1996 to 2005. Nitrate concentrations ranged from 2.1 to $15 \mathrm{mg}$ $\mathrm{L}^{-1}$ at the watershed outlet and 74.3\% (150 out of 202 samples) exceeded the maximum 
contamination level of $10 \mathrm{mg} \mathrm{L}^{-1}$ (Schilling et al. 2006). Mean annual nitrate concentrations ranged from 8.2 to $11.5 \mathrm{mg} \mathrm{L}^{-1}$ and averaged $9.5 \mathrm{mg} \mathrm{L}^{-1}$, whereas nitrate export from Squaw Creek averaged $26.1 \mathrm{~kg} \mathrm{ha}^{-1}(23.3 \mathrm{lb}$ $\mathrm{ac}^{-1}$ ) (standard deviation $11.8 \mathrm{~kg} \mathrm{ha}^{-1}[10.5$ $\mathrm{lb} \mathrm{ac^{-1 }}$ ) for the 10-year monitoring period. Nitrate concentrations at the Squaw Creek outlet were found to have increased $1.9 \mathrm{mg}$ $\mathrm{L}^{-1}$ during the monitoring project when row crop land use increased from 3,282 ha $(8,110 \mathrm{ac})$ to $3,535(8,735 \mathrm{ac})$ (Schilling and Spooner 2006).

Nitrate concentrations were also measured in two smaller subbasins corresponding to subbasins 19 and 24 in this study (figure 1). Surface water samples were collected weekly to bimonthly during the April to September period only. In the two monitored subbasins, annual nitrate concentrations increased significantly between 1996 and 2005 due to land-use conversions. In subbasins 19 and 24, $29.8 \mathrm{ha}(73.6 \mathrm{ac})$ and $64.3 \mathrm{ha}(158.9 \mathrm{ac})$ of CRP grasslands were converted to row crop production between 1996 and 2000, corresponding to $26 \%$ and $29 \%$ of their respective watershed areas. Mean annual nitrate concentrations in subbasin 19 increased from 2 to $3 \mathrm{mg} \mathrm{L}^{-1}$ in the 1996 to 1998 period to values greater than $10.2 \mathrm{mg} \mathrm{L}^{-1}$ in 2003 to 2005. Similarly in subbasin 24 , mean annual nitrate concentrations increased from values less than $5 \mathrm{mg} \mathrm{L}^{-1}$ prior to 2000 to annual concentrations greater than $15 \mathrm{mg} \mathrm{L}^{-1}$ in 2005. Since flow was not measured at the subbasin sites, we could not calculate nitrate loads for these areas.

Soil and Water Assessment Tool Model. SWAT is a watershed-scale water quality model that operates on a daily time step and is capable of simulating detailed land use and land management operations. It was developed by the USDA Agricultural Research Service and has experienced continuous evolution with several hundred peer-reviewed publications since the first releases in the early 1990s (Gassman et al. 2007; CARD 2009b). In SWAT, a watershed is divided into multiple subbasins, which are further subdivided into hydrologic response units (HRU) that consist of homogeneous land use, management, and soil characteristics. Streamflow generation, sediment yield, and nonpoint-source loadings from each HRU are summed, and the resulting loads are routed through channels, ponds, and/or reservoirs to the watershed outlet. Key components of SWAT include hydrol-

\section{Figure 2}

2005 common land unit (CLU)-based land-use data for the Squaw Creek watershed.

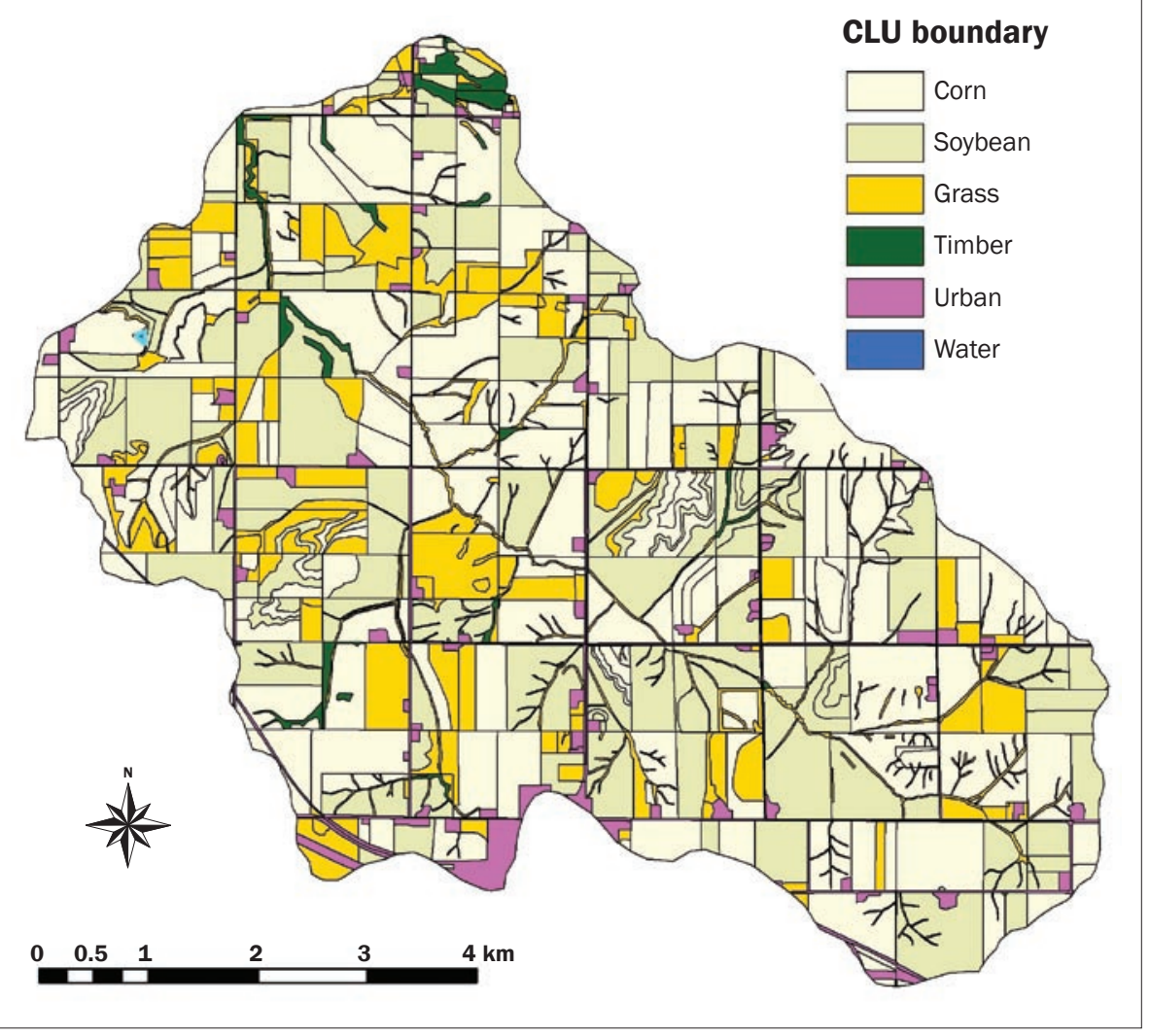

ogy, plant growth, erosion, nutrient transport and transformation, pesticide transport, and management practices. Outputs provided by SWAT include streamflow and in-stream loading or concentration estimates of sediment, organic nitrogen, nitrate, organic phosphorous, soluble phosphorus, and pesticides. Previous applications of SWAT for streamflow and/or pollutant loadings have compared favorably with measured data for a variety of watershed scales (Gassman et al. 2007).

Input Data and Modeling Setup. A modeling framework was established for the Squaw Creek watershed using SWAT, the i_SWAT interface (CARD 2009a), the ArcView SWAT interface (AVSWATX) (Di Luzio et al. 2004), other software such as a baseflow separation program and a load estimator regression analysis tool, and an input database containing topography, land use, soil, and land management information. A 5 $\mathrm{m}$ (16.4 ft) digital elevation model (USGS 2008a), used to generate topographic data, and Soil Survey Geographic (SSURGO) data (USDA NRCS 2008) were obtained from the Iowa Department of Natural Resources (IDNR 2008). Measured precipitation data was obtained from two sources (figure 1): a tipping-bucket rain gage located at the mouth of the watershed and a climate station located near the City of Newton outside of the watershed boundaries, which is operated by the National Weather Service (NWS) Cooperative Observer Program (COOP) (ISU 2009). Daily maximum and minimum temperature data were also obtained from the Newton NWS COOP station.

A detailed land-use and conservation practice dataset was created on the basis of a field-level survey completed in May and June 2005 (C. Kiepe 2005. Personal communication. Private consultant, Hampton, Iowa). Using a map of common land units (CLU), a tablet personal computer was used with a geographic information system interface to enter land use and conservation practices descriptions for each CLU into the geographic information system database. Conservation practices mapped included tillage practices, grass waterways, terraces, CRP grasslands, and other common USDA-funded conservation practices. Figure 2 shows CLU-based land-use information for year 2005.

Typical fertilizer application rate data were obtained for the watershed. Nitrogen fertil- 


\section{Table 1}

List of calibrated parameters and their final values.

\begin{tabular}{llll}
\hline Parameter & Default & Range & Calibrated value \\
\hline For watershed hydrology and streamflow & & & $-10 \%$ \\
\hline Curve number (CN2)* & Standard list & $\pm 10 \%$ & Reduced by 0.02 \\
Soil available water capacity (SOL_AWC) & Soil database & \pm 0.04 & 9 days \\
Groundwater delay coefficient (GW_DELAY) & 31 days & 0 to 100 days & 0.7 \\
Baseflow recession coefficient (GW_Alfa) & 0.048 & 0.1 to 1.0 & 6 \\
Surface runoff lag coefficient (SURLAG) & 4 & 0.1 to 10 & 3.5 \\
\hline For nitrate-nitrogen & & & 0.1 \\
\hline Organic $\mathrm{N}$ enrichment ratio (ERORGN) & 0 & 0.05 & 0.25 \\
Organic $\mathrm{N}$ settling rate $(\mathrm{RS} 4)$ & 0.05 & 0.01 to 0.10 & 0.9 \\
Hydrolysis of organic $\mathrm{N}_{\text {to }} \mathrm{NH}_{4}(\mathrm{BC} 3)$ & 0.21 & 0.5 to 0.4 & 2.0 \\
Biological oxidation of $\mathrm{NH}_{4}$ to $\mathrm{NO}_{2}(\mathrm{BC} 1)$ & 0.55 & 0.1 to 1.0 & \\
Biological oxidation of $\mathrm{NO}_{2}$ to $\mathrm{NO}_{3}(\mathrm{BC} 2)$ & 1.1 & 0.0 & \\
\hline
\end{tabular}

Notes: $\mathrm{N}=$ nitrogen. $\mathrm{NH}_{4}=$ ammonia. $\mathrm{NO}_{2}=$ nitrite. $\mathrm{NO}_{3}=$ nitrate.

* Abbreviations in parentheses indicate the notation used in the Soil and Water Assessment Tool model.

izer rates were consistent with application rates reported for Jasper County in the USDA NASS Annual Agricultural Statistics (2009), whereas the phosphorus rate information was obtained from a survey of local fertilizer dealers in the Raccoon River watershed (Schilling et al. 2008b). Nitrogen applications are typically applied for corn production in the form of anhydrous ammonia at a total rate of $190 \mathrm{~kg} \mathrm{ha}^{-1}$ (169.6 $\mathrm{lb} \mathrm{ac}^{-1}$ ), while phosphorus is usually applied in the form of diammonium phosphate at a rate of $187.5 \mathrm{~kg}$ $\mathrm{ha}^{-1}\left(167.4 \mathrm{lb} \mathrm{ac}^{-1}\right)$. It was assumed that the anhydrous ammonia was applied in the fall on October 25 and that diammonium phosphate was applied in the spring on April 26 before corn planting.

The digital elevation model-derived topographic data and a 1:100,000 scale National Hydrography Dataset (USGS 2008b) were used to delineate the stream network and subbasins for the SWAT simulations, resulting in a watershed configuration of 27 subbasins (figure 1). The HRUs were then created by combining the 2005 CLU-based land-use data with the SSURGO soil data. All together, a total of 1,662 HRUs were created for modeling. The appropriate precipitation data was assigned to each subbasin using AVSWATX, based on the proximity of the two climate stations (figure 1) to the centroid of each subbasin. The Newton NWS COOP temperature data were distributed across all of the SWAT subbasins. The SWAT model was then run on a daily time step for 1994 to 2004 with three distinct simulation periods: a two-year (1994 to $1995)$ initialization period, five-year (2000 to 2004) calibration period, and four-year (1996 to 1999) validation period. Other important SWAT simulation options that were invoked for this study included using the Hargreaves method to estimate potential evapotranspiration, the Muskingum method for channel flow routing simulation, and the USDA Natural Resources Conservation Service runoff curve number method for partitioning daily precipitation between surface runoff and infiltration.

Daily streamflow data collected from a sampling site located at the watershed outlet were used for flow calibration and validation. The model was first calibrated for annual flow volumes, then for monthly flow volumes and seasonal trends. Several model parameters, which affect the seasonal trends, recession, daily peaks, and other flow characteristics, were adjusted within the recommended ranges to obtain final calibrated values (table 1). The nitrate calibration was performed in a manner to match SWAT simulated nitrate loads to the measured values at the monitoring site. It should be noted that "measured" in this case does not refer to the actual measured nitrate loads, but rather to loads estimated from weekly or biweekly samples using the USGS Load Estimator (LOADEST) regression model (Runkel et al. 2004). Statistical evaluation of modeling results was assessed using two performance criteria: coefficient of determination $\left(r^{2}\right)$ and Nash-Sutcliffe's coefficient (E) (Nash and Sutcliffe 1970). The $r^{2}$ value is an indicator of the strength of relationship between measured and simulated values, whereas the $\mathrm{E}$ value measures how well the simulated values agree with the measured value. Values of $r^{2}$ can range from zero to one while the $\mathrm{E}$ ranges from $-\infty$ to 1 . A value of one is considered a perfect match with the measured data for both statistics. The mean of the measured data would be considered to be a better predictor than the model output when an $\mathrm{E}$ value is equal to or less than zero. These statistics have been used in many previously published studies for verifying the SWAT simulation accuracy (Gassman et al. 2007).

The SWAT model calibration required adjustment of several model parameters within their recommended ranges. The calibration process included adjusting the baseflow ratio to the surface runoff, amount of evapotranspiration, and total water yield. Table 1 listed all parameters used in the calibration with their typical defaulted values, recommended ranges, and final calibrated values. For example, the curve number values were reduced by $10 \%$ of the standard curve number values for a given land use, soil type, and antecedent moisture condition. The calibration of nitrate transport in the watershed also required adjustments of the SWAT model parameters (within the recommended ranges) related to nitrogen cycle dynamics and in-stream nitrogen. Table 1 lists all the nitrate-related calibration parameters, including the final values determined for the Squaw Creek watershed simulations.

Land-Use Change Scenarios. In this study, four spatial configurations of landuse change in the Squaw Creek watershed were modeled to improve understanding of targeting strategies for the period of 1990 to 2005 , using the measured precipitation and temperature data distributed across the 


\section{Figure 3}

Average precipitation and monthly streamflow comparison at the watershed outlet for the calibration (2000 to 2004) and validation (1996 to 1999) periods.

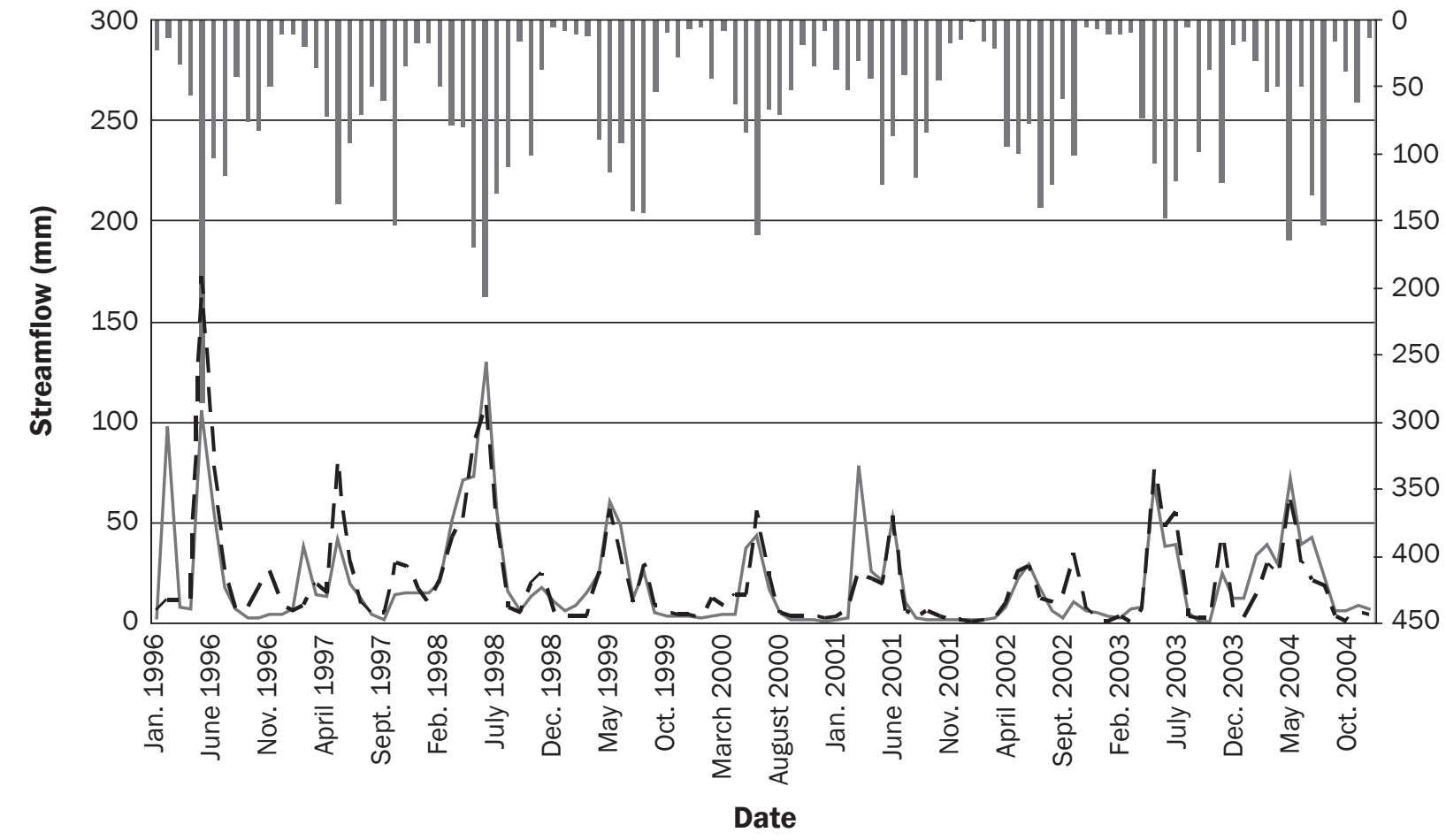

Legend

Precipitation Measured - - Simulated

simulated subwatersheds in the manner previously described. In scenario 1 , the observed land-use change in the watershed was modeled to assess the impact of conversion of CRP grasslands back to row crop. While the trajectory of land-use change with the scenario is opposed to the goals of this study to evaluate effects of perennial reintroduction to reduce nitrate loads, the model scenario allows the comparison of the observed relation between land use and nitrate loads at two points in time (and thus also serves as a further verification of the SWAT accuracy). One can use this scenario to, in essence, turn the pages of a book back and forth in time to see the effects of land-use change on water quality. Scenario 1 was expanded specifically to examine the effects of land-use change on nitrate loads in subbasins 19 and 24, where land-use changes occupied a much greater proportion of the overall watershed areas and greatly impacted water quality as described in Schilling et al. (2006).

In scenario 2, all row crops defined as highly erodible lands (HEL) were converted to grassland (see Dick and Putnam [1986] for a description of HEL land). While it is commonly understood that crops farmed on HEL soils may have severe erosion potential, this scenario was used to estimate the degree of load reduction that could be achieved if these areas were also conservation targets for nitrate. There may be dual benefits for reducing nitrate loads from HEL areas planted into grasslands, while also reducing potential soil loss. In scenario 3, grassland reintroduction was targeted in five subbasins located in the upper portion of the watershed (subbasins 1 through 5) (figure 1). During the 10-year monitoring project, downstream nitrate concentrations were significantly related to upstream concentrations, and the results indicated that upper basin areas exerted a proportionally large effect on the overall watershed export. Hence, scenario 3 was used to gauge the magnitude of nitrate load reduction that could be achieved if land-use change occurred only in the upper regions of a watershed. In scenario 4, grassland reintroduction was targeted to subbasins that included the floodplain of Squaw Creek (subbasins 6, 11, 12, 20, 21, 23, and 27).
SWAT identifies floodplains at the HRU level based on the soil properties. Even though the HRUs are not spatially defined within a subbasin, subbasins within a watershed are spatially referenced. Here we did not target landscape position specifically, but we did target floodplains using the subbasin approach. In adjacent Walnut Creek watershed, recent analysis suggested that groundwater recharge may be concentrated in the floodplain of the watershed, with the floodplain comprising $17 \%$ of the land area but producing $34 \%$ of the watershed groundwater recharge (Schilling 2009). Thus, the objective of scenario 4 was to evaluate whether planting grasslands in floodplains would sufficiently reduce groundwater recharge and result in proportionally larger nitrate load reductions in the watershed.

\section{Results and Discussion}

Calibration and Validation. The annual water balance for the Squaw Creek watershed computed with SWAT found that, on average, streamflow comprises $29 \%$ of precipitation (223 $\mathrm{mm}$ [8.8 in]), and annual 
evapotranspiration comprises $71 \%$ of precipitation (545 $\mathrm{mm}$ [21.5 in]). The streamflow component includes surface runoff, lateral flow, and groundwater flow. Groundwater recharge contributes to lateral flow, shallow aquifer (groundwater flow), and deep aquifer. SWAT assumes $5 \%$ of the recharge as a loss to the deep aquifer. Figure 3 shows the graphical comparison of the measured and the SWAT-simulated monthly streamflow at the watershed outlet for both the calibration and validation periods. Visual inspection indicates that the SWAT monthly flow predictions replicated the measured data well, except for a few of the months. Statistical evaluation (table 2) yielded monthly $r^{2}$ and $E$ values of 0.71 and 0.69 for the calibration period (2000 to 2004) and 0.65 and 0.56 for the validation period (1996 to 1999). The monthly statistics were stronger than the annual statistics for some of the time periods; the annual statistics can be strongly affected by a large bias during a single year over the short time comparisons of four or five years.

It was evident during calibration that there were a few months when precipitation and discharge were not in sync, mainly for conditions when discharge was elevated but little or no precipitation was recorded (i.e., February, May, and June of 1996; February

Table 2

Statistical evaluation of simulated and measured flow and nitrate results.

\begin{tabular}{llll}
\hline Variable & Time step & $\boldsymbol{r}^{2}$ & E \\
\hline Streamflow & & & \\
\hline Calibration (2000 to 2004) & Annual & 0.47 & 0.44 \\
& Monthly & 0.71 & 0.69 \\
Validation (1996 to 1999) & Annual & 0.80 & 0.78 \\
& Monthly & 0.65 & 0.56 \\
\hline Nitrate load & & & 0.82 \\
\hline Calibration (2000 to 2004) & Annual & 0.42 & 0.72 \\
Validation (1996 to 1999) & Monthly & 0.61 & 0.91 \\
& Annual & 0.54 & 0.77 \\
\hline
\end{tabular}

Notes: $r^{2}=$ the coefficient of determination. $\mathrm{E}=$ the Nash-Sutcliffe's coefficient.

and May of 1997; and March of 2001). This is likely due to the occurrence of localized storms that may have missed the sparsely located weather stations. Because the watershed is small and streamflow is very flashy, localized rainfall hotspots may have rapidly contributed to discharge peaks with little or no rainfall measured at regional weather stations. The model performance increased significantly both on an annual and monthly basis if the poor months were removed from the comparison, resulting in $r^{2}$ and $\mathrm{E}$ statistics ranging from 0.61 to 0.97 with the majority of statistics exceeding 0.80 . Overall, the statistical analysis of calibration/validation results can be viewed as quite strong for the annual and monthly results, when viewed in the context of the suggested criteria by Moriasi et al. (2007).

The simulated nitrate load generally followed a similar pattern as that of streamflow and replicated well the measured data trends (figure 4). Monthly $r^{2}$ and E statistics (table 2) of 0.61 and 0.72 were computed for the calibration period (2000 to 2004), and corresponding values of 0.67 and 0.77 were determined for the validation period (1996 to 1999). The monthly $r^{2}$ statistics were

\section{Figure 4}

Comparison of monthly nitrate-nitrogen loadings at the watershed outlet for the calibration (2000 to 2004) and validation (1996 to 1999) periods.

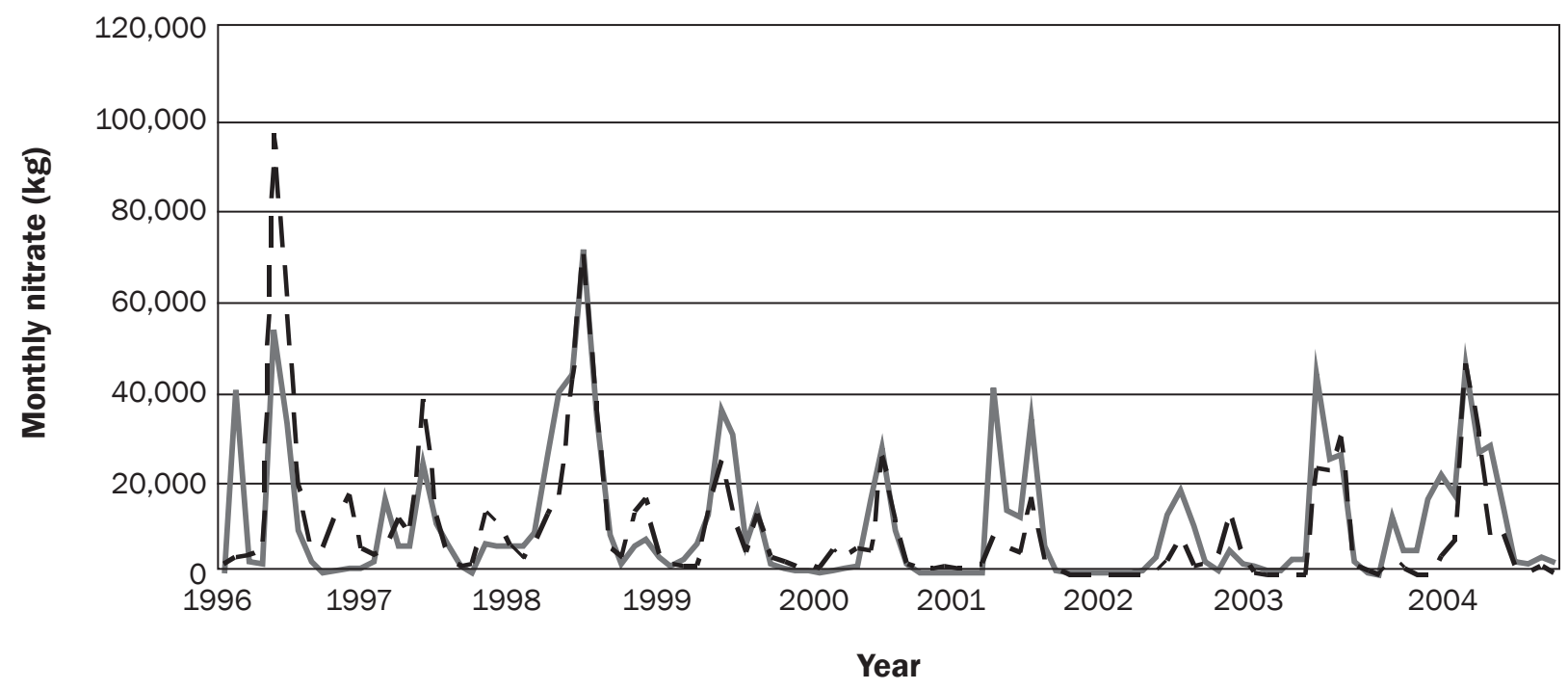

Legend

Measured $\quad-$ Simulated 
somewhat stronger than the annual $r^{2}$ values, similar to what was found for the streamflow evaluations. The model performance increased again if the previously described poor months were removed from the comparison, resulting in the $r^{2}$ and $\mathrm{E}$ statistics ranging from 0.56 to 0.94 . Overall, the nitrate loading predictions were considered reasonable on an average annual and monthly basis, considering that the measured nitrate loads were estimates developed from weekly and/ or biweekly samples. The results are strong relative to statistics reported by Gassman et al. (2007) for several SWAT studies, which included testing of the model for nitrate movement, and are also consistent with criteria suggested by Moriasi et al. (2007).

Water Yield and Nitrate Loading Patterns. Average annual water yield in Squaw Creek ranged from 189 to $284 \mathrm{~mm}$ (7.4 to $11.2 \mathrm{in}$ ) with greater water yield near the watershed outlet. This area of the basin is sandier than more distant areas in the watershed because of its proximity to the sandy floodplain of the South Skunk River. The subbasins along the Squaw Creek floodplain corridor had the lowest average water yield in the basin. Average annual nitrate load from subbasin outlets under the calibrated baseline condition in 2005 indicated minor variation among the 27 subbasins (figure 5). Subbasins with nitrate loads greater than $20 \mathrm{~kg} \mathrm{ha}^{-1}$ $\left(17.9 \mathrm{lb} \mathrm{ac}^{-1}\right)$ were located in the upper and lower regions of Squaw Creek watershed, whereas three subbasins in the central portion of the basin containing more pasture exhibited nitrate losses less than $14.5 \mathrm{~kg} \mathrm{ha}^{-1}$ $\left(12.9 \mathrm{lb} \mathrm{ac}^{-1}\right.$ ) (figure 5). Overall, the average annual nitrate loss from the 27 subbasins was $18.1 \mathrm{~kg} \mathrm{ha}^{-1}\left(16.2 \mathrm{lb} \mathrm{ac}^{-1}\right)$ with a standard deviation of only $2.5 \mathrm{~kg} \mathrm{ha}^{-1}\left(2.2 \mathrm{lb} \mathrm{ac}^{-1}\right)$.

Thus, while the modeling results suggested that some subbasins may be contributing more nitrate load than other subbasins, the range of average annual nitrate loads exported from the subbasins was not particularly large. This was not surprising given the similar land-use patterns exhibited across the watershed. In the case of Squaw Creek, it would be difficult to use the model to identify and target specific "hot spots" most responsible for the elevated nitrate export when none stand out above the background. However, this is not an uncommon occurrence when modeling watersheds dominated by a single land use (in this case, row crop). In Squaw Creek, the amount of grassland in a subbasin provided a

\section{Figure 5}

Spatial distribution of average annual (a) water yield and (b) nitrate loading across the watershed.

(a)
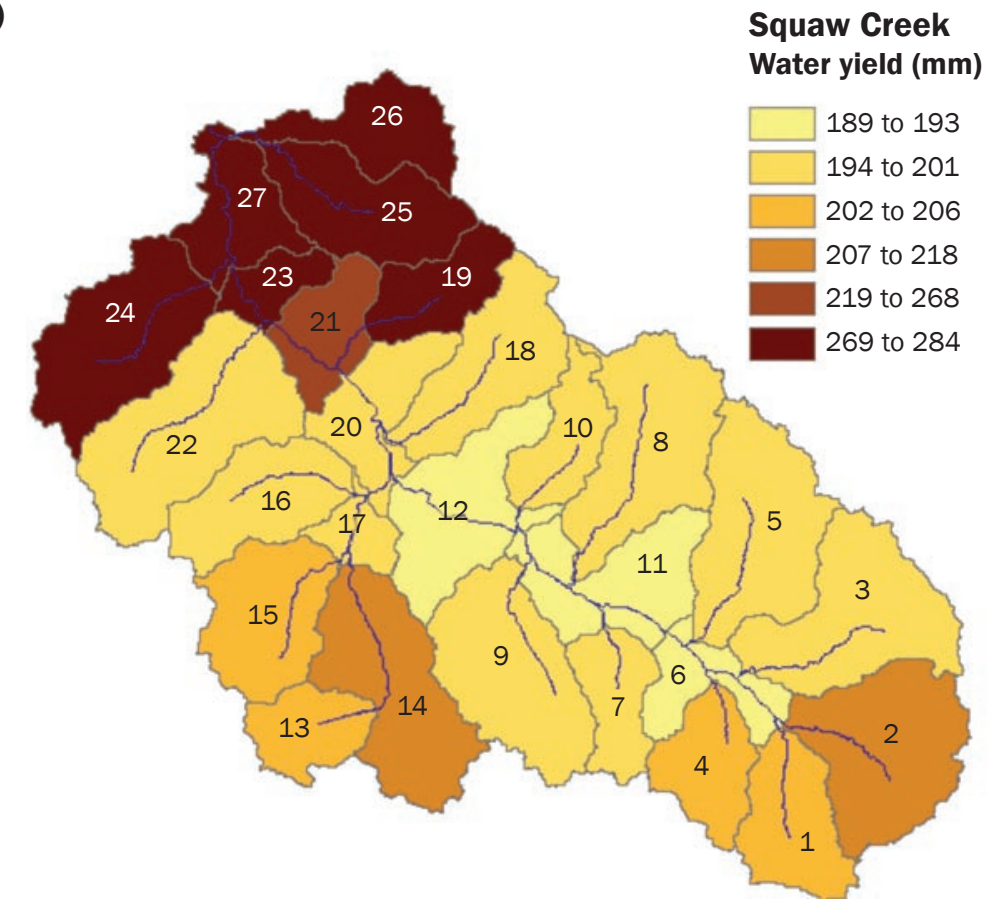

(b)

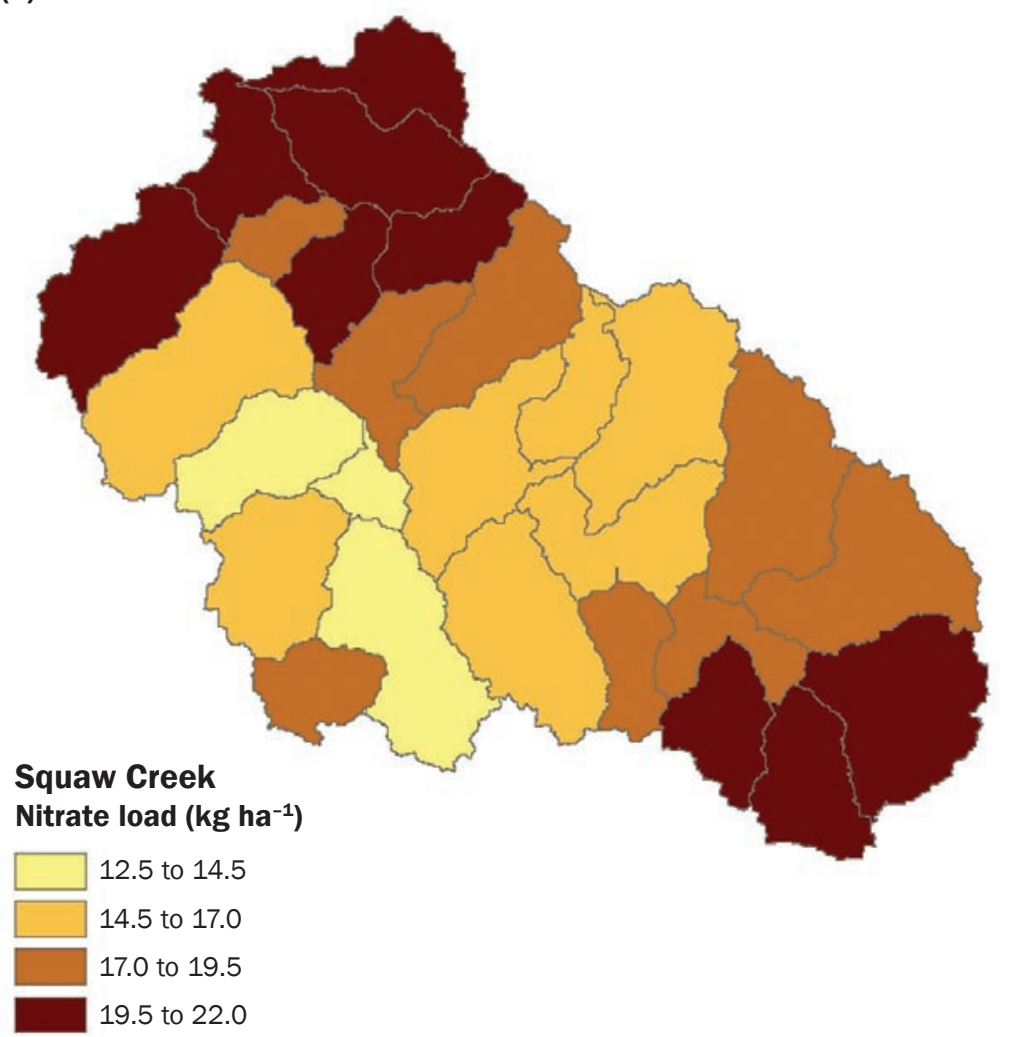


Table 3

Land-use changes between 1990 and 2005 and their estimated impacts on nitrate loads (scenario 1).

\begin{tabular}{|c|c|c|c|c|c|c|}
\hline & \multicolumn{2}{|c|}{ Subbasin 19} & \multicolumn{2}{|c|}{ Subbasin 24} & \multicolumn{2}{|c|}{ Squaw Creek watershed } \\
\hline & 1990 & 2005 & 1990 & 2005 & 1990 & 2005 \\
\hline $\begin{array}{l}\text { Row crops (ha) } \\
\text { (corn and soybean) }\end{array}$ & 38.1 & 67.9 & 119.5 & 183.8 & 3,282 & 3,535 \\
\hline $\begin{array}{l}\text { Grassland (ha) } \\
\quad \text { (pasture and CRP) }\end{array}$ & 74.8 & 45.0 & 97.8 & 33.4 & 1,013 & 765 \\
\hline Urban (ha) & 1.2 & 1.2 & 8.1 & 8.2 & 243 & 243 \\
\hline Forest (ha) & 0 & 0 & 0 & 0 & 71 & 66 \\
\hline $\begin{array}{l}\text { Nitrate load at the } \\
\text { outlet (kg) }\end{array}$ & 778 & 1,464 & 2,772 & 4,244 & 108,199 & 115,830 \\
\hline $\begin{array}{l}\text { Nitrate increase per } \\
\text { new row crop area } \\
\text { added }\left(\mathrm{kg} \mathrm{ha}^{-1}\right)\end{array}$ & & 26 & & 23 & & 30 \\
\hline
\end{tabular}

measure to differentiate subbasins with lower nitrate loads from subbasins with higher loads typical of background conditions. Thus, the goal of the targeting scenarios was to identify where grasslands could be better targeted in Squaw Creek watershed to achieve nitrate load reductions at the watershed outlet.

Land-Use Changes and Nitrate Load Scenarios. The calibrated model was first run for 10 years (1995 to 2004) to establish a baseline for comparison of scenario results. Each land-use change scenario was run for the same period, and then average annual changes were compared with the baseline results. For scenario 1, modeled nitrate loads increased substantially in the Squaw Creek watershed, resulting from increasing row crop land use from 1990 to 2005 (table 3). At the watershed outlet, average annual nitrate loads increased over $7,600 \mathrm{~kg}(16,720 \mathrm{lb})$, equating to additional loss of approximately $30.2 \mathrm{~kg}$ of nitrate $\mathrm{ha}^{-1}$ of new row-crop land use. In the two smaller subbasins (19 and 24), nitrate loads of row crop conversion increased 26.1 and $22.9 \mathrm{~kg} \mathrm{ha}^{-1}\left(23.3\right.$ and $20.5 \mathrm{lb} \mathrm{ac}^{-1}$ ) from 1990 to 2005 (table 3). These nitrate loss rates were similar to values reported in western Iowa (Burkart et al. 2005), where watersheds were found to yield nitrogen losses of 18 to $43 \mathrm{~kg} \mathrm{ha}^{-1}$ (16.1 to $38.4 \mathrm{lb} \mathrm{ac}^{-1}$ ) with a median loss of $32 \mathrm{~kg} \mathrm{ha}^{-1}\left(28.6 \mathrm{lb} \mathrm{ac}^{-1}\right)$.

While the trajectory of land-use conversion was opposite to the goals of this study, it is worthwhile to consider this counterfactual scenario. Had the CRP grassland present in 1990 remained in Squaw Creek watershed and in subbasins 19 and 24, modeling results suggest that nitrate loads would have been 6.6\% lower in Squaw Creek compared to current average annual loads. Similarly, nitrate loads at subbasins 19 and 24 may have been $46.9 \%$ and $34.7 \%$ lower than they are today. These results demonstrate the implication of converting grasslands to row crops on nitrate export.

It is interesting to note that the increase in nitrate loss per area of row crop conversion was slightly higher in the entire watershed as compared to the smaller subbasins (table 3). However, water quality data from the 10-year monitoring project indicated only a $1.9 \mathrm{mg}$ $\mathrm{L}^{-1}$ increase in stream nitrate concentrations at the watershed outlet, as compared to more than a $10 \mathrm{mg} \mathrm{L}^{-1}$ increase in subbasins 19 and 24. The difference between unit-area loading increases and measured increasing watershed nitrate concentrations likely stems from the relative sizes of the watershed areas. At the watershed outlet of Squaw Creek, an increase in nitrate loading rates in various watershed areas was averaged over the entire basin, effectively diluting the impact. In small subbasins like 19 and 24, increasing nitrate loss with land-use change was rapidly translated to increasing stream nitrate concentrations. Modeled annual flow-weighted nitrate concentrations increased from 2.1 to $4.4 \mathrm{mg} \mathrm{L}^{-1}$ at the outlet of subbasin 19 and increased from 3.9 to $6.4 \mathrm{mg} \mathrm{L}^{-1}$ at subbasin 24 from 1990 to 2005 . Hence, modeled nitrate concentrations approximately doubled from the conversion of CRP grassland to row crop. While these increases are substantial, they were, in fact, less than the increases observed during the monitoring project (an increase of $10 \mathrm{mg} \mathrm{L}^{-1}$ over four to five years). This indicates that SWAT is not able to fully replicate this relatively quick and substantial increase in nitrate loss due to the conversion back to row crops and suggests that future improve- ments may be needed to the model to better capture this phenomenon. The effects of land-use conversion on stream nitrate loads and concentrations is noteworthy if rapid expansion of the ethanol industry continues to occur in the future, which could provide the impetus for future land-use conversions of CRP to row crops (Schilling et al. 2008; Secchi et al. 2008).

The same scale effect, although in reverse, was observed in the adjacent Walnut Creek watershed. The rate of nitrate concentration decrease following prairie restoration of row crop lands was much greater in small watersheds than measured at the watershed outlet (Schilling and Spooner 2006). A 1.2\% decrease in stream nitrate concentration over 10 years was observed at the watershed outlet, compared to as much as a $3.4 \mathrm{mg}$ $\mathrm{L}^{-1}$ reduction observed in smaller subbasins. By the same token, should the response of stream nitrate loads to decreasing row crop land use in Squaw Creek be the same as the increasing response, the hypothetical nitrate concentration reduction should be greater in the smaller subbasins. However, Schilling and Spooner (2006) cautioned that the rate of nitrate concentration increase in Squaw Creek was more than double the rate of nitrate concentration decrease in Walnut Creek. Thus, it would be unlikely that the nitrate decrease following land conversion would result in the same magnitude of decrease as observed for the nitrate concentration increase.

Table 4 presents nitrate loading reduction due to land use change proposed in scenarios 2, 3 and 4. In scenario 2, nitrate loads at the Squaw Creek outlet were reduced $47.4 \%$ from the baseline condition by converting 
Table 4

Scenarios 2 to 4: Estimated effects of land-use changes in nitrate-nitrogen loading in the watershed.

\begin{tabular}{lccc}
\hline & $\begin{array}{l}\text { Scenario 2 } \\
\text { (All HEL soil row } \\
\text { crops to grassland) }\end{array}$ & $\begin{array}{l}\text { Scenario 3 } \\
\text { (All row crops in upper } \\
\text { basin to grassland) }\end{array}$ & $\begin{array}{l}\text { Scenario 4 } \\
\text { (All row crop in floodplain } \\
\text { subbasins to grassland) }\end{array}$ \\
\hline Affected subbasins & All & $1,2,3,4,5$ & $6,11,12,20,21,23,27$ \\
Row crop area (ha) & 1,915 & 898 & 692 \\
Nitrate load at the watershed outlet (kg) & 60,897 & 97,234 & 106,344 \\
Nitrate load reduced from baseline (kg) & 54,933 & 18,596 & 9,486 \\
Percent nitrate reduction & 47.4 & 16.1 & 8.2 \\
Nitrate reduction per row crop area treated (kg ha-1) & 29 & 21 & 14 \\
\hline
\end{tabular}

Note: Baseline nitrate at the watershed outlet is $115,830 \mathrm{~kg} . \mathrm{HEL}=$ highly erodible lands.

all row crops on HEL to perennial grassland. This reduction translated to a nitrate load reduction of $28.7 \mathrm{~kg} \mathrm{ha}^{-1}\left(25.6 \mathrm{lb} \mathrm{ac}^{-1}\right)$. In other words, converting $40.7 \%$ of the land area in Squaw Creek from row crop to grassland resulted in a nitrate load reduction of $47.4 \%$. Converting land in upper regions of the Squaw Creek watershed (scenario 3) and in the floodplain (scenario 4) was less efficient based on the area of land affected and the nitrate load reduction achieved. The nitrate reduction per land area converted was substantially less for scenarios 3 and 4 , ranging from $20.7 \mathrm{~kg} \mathrm{ha}^{-1}\left(18.5 \mathrm{lb} \mathrm{ac}^{-1}\right)$ to 13.7 $\mathrm{kg} \mathrm{ha}^{-1}\left(12.2 \mathrm{lb} \mathrm{ac}^{-1}\right)$, respectively. Scenario 3 reduced nitrate loads by $16.1 \%$ by converting $19.1 \%$ of the land area, whereas scenario 4 reduced nitrate loads by $8.2 \%$ by converting $14.7 \%$ of the land area. The results suggest that converting HEL land from row crop to perennial grassland could achieve a greater nitrate load reduction for a proportionate land area treated than targeting lands in upper watershed subbasins or along the floodplain. Thus existing programs already targeting HEL lands for land retirement to reduce sediment erosion may serve a double purpose by being the lands most appropriate for reducing nitrate loading rates to streams.

The effectiveness of targeting nitrate load reductions by HEL and floodplain area in the Squaw Creek watershed was compared to a similar SWAT modeling effort completed for the much larger South Raccoon River watershed $(253,900$ ha $[627,387 \mathrm{ac}])$, located in Ecoregion 47 in west central Iowa (Jha et al. 2010). In the South Raccoon River watershed, HEL row crops comprised $36.1 \%$ of the watershed area. Converting all the HEL row crops to grassland resulted in a nitrate load reduction of $28.8 \%$ at the watershed outlet. The nitrate load reduction associated with HEL conversion at a larger scale in the South Raccoon was similar to the local effect modeled for Squaw Creek. However, the impact of converting floodplain row crops in the South Raccoon was much greater than observed in Squaw Creek. In the South Raccoon, floodplain row crops comprised $11.9 \%$ of the watershed area. Converting all the floodplain row crops to grassland resulted in a $15.7 \%$ reduction in nitrate loads. This would suggest that, for the same amount of land treated, converting floodplain row crops to grassland in the South Raccoon River watershed would result in a proportionally larger nitrate load reduction compared to targeting HEL ground. However, it should be noted that the SWAT assessment of the South Raccoon River watershed used soil types to target only soils classified as alluvium for land-use change, whereas for Squaw Creek, all row crop lands in the entire subbasin containing the floodplain were converted from row crop to grass. Hence, the difference between the two models may be a result of using different targeting criteria. Despite mixed effectiveness, targeting floodplains for row crop conversion should be considered a viable BMP for agricultural watersheds because these areas provide other ecosystem services in addition to nitrate load reductions, like floodway buffering and wildlife corridors. Overall, the comparison of the Squaw Creek results with the South Raccoon results suggests that targeting solutions using land-use change for nitrate load reductions may be unique to watershed areas, implying that caution should be used before applying a one-size-fits-all approach to landscape management.

\section{Summary and Conclusions}

The Squaw Creek watershed in south central Iowa is an intensively cropped agricultural landscape typical of much of Iowa and the Corn Belt region of the United States. Like many other watersheds, nitrate loads are an environmental concern, and targeting strategies are needed to identify areas where nitrate loading rates can be reduced with greater efficiency. The use of perennial cover, such as CRP, for nitrate reduction is a proven BMP, but studies are needed to provide guidance for selecting areas for land-use conversion that may achieve the greatest nitrate load reduction for the land area treated. Results from a SWAT model simulation for the Squaw Creek watershed suggested that nitrate losses are sensitive to land-use change. Monitoring data demonstrated and modeling results confirmed that changing land use from CRP to row crop increased nitrate loads substantially at the watershed and subbasin scales. Nitrate leaching in excess of $23 \mathrm{~kg} \mathrm{ha}^{-1}$ (20.5 $\mathrm{lb} \mathrm{ac}{ }^{-1}$ ) occurred in response to land-use conversion to row crop. Had the same watershed regions remained in grassland, nitrate export may have been $7 \%$ to $47 \%$ lower than measured today.

Modeling results suggested that targeting row crops on HEL for land-use conversion to perennial cover may provide an efficient solution to reduce nitrate loads. In Squaw Creek, nitrate loads were expected to be reduced by $47.4 \%$, following conversion of $40.7 \%$ of the HEL land area. While this amount of conversion is certainly not feasible, results suggest that targeting HEL may be an efficient means of achieving nitrate reduction while serving other nonpoint source pollution reduction efforts. Converting row crops to grasslands in upper basin regions reduced nitrate losses at the watershed outlet by reducing nitrate loads where they tend to be highest. Finally, targeting floodplains for grassland conversion was not as effective in Squaw Creek, nor as effective as observed elsewhere, but the approach holds promise for achieving nitrate load reductions while providing other ecosystem services. In conclusion, results from the SWAT model simulations provide much needed guidance on how to begin targeting nitrate load reductions more effectively in agricultural watersheds. 


\section{Acknowledgements}

This research was funded from support provided by the USDA Cooperative State Research, Extension, and Education Service (Project No. 20045113003120).

\section{References}

Arnold, J.G., and P.M. Allen. 1999. Automated methods for estimating baseflow and groundwater recharge from streamflow record. Journal of American Water Resources Association 35(2):411-424.

Arnold, J.G., and N. Fohrer. 2005. SWAT2000: Current capabilities and research opportunities in applied watershed modeling. Hydrological Processes 19(3):563-572.

Arnold, J.G., R. Srinivasan, R.S. Muttiah, and J.R. Williams. 1998. Large area hydrologic modeling and assessment part I: Model development. Journal of the American Water Resources Association 34(1):73-89.

Brye, K.R., T.W. Andraski, W.M. Jarrell, L.G. Bundy, and J.M. Norman. 2002. Phosphorus leaching under a restored tallgrass prairie and corn agroecosystem. Journal of Environmental Quality 31:769-781.

Brye, K.R., J.M. Norman, L.G. Bundy, and S.T. Gower. 2000. Water budget evaluation of prairie and maize ecosystems. Soil Science Society of America Journal 64:715-725

Brye, K.R., J.M. Norman, L.G. Bundy, and S.T. Gower. 2001. Nitrogen and carbon leaching in agroecosystems and their role in denitrification potential. Journal of Environmental Quality 30:58-70.

Burkart, M., D. James, M. Liebman, and C. Herndl 2005. Impacts of integrated crop-livestock systems on nitrogen dynamics and soil erosion in western Iowa watersheds. Journal of Geophysical Research 110: G01009, doi:10.1029/2004JG000008.

CARD (Center for Agricultural and Rural Development). 2009a. CARD interactive software programs. Ames, IA: Center for Agricultural and Rural Development, Iowa State University. http://www.card.iastate.edu/ environment/interactive_programs.aspx.

CARD. 2009b. SWAT literature database for peer-reviewed journal articles. Ames, IA: Center for Agricultural and Rural Development, Iowa State University. https:// www.card.iastate.edu/swat_articles/.

Chaplot, V., A. Saleh, D.B. Jaynes, and J.G. Arnold. 2004 Predicting water, sediment, and $\mathrm{NO}_{3}-\mathrm{N}$ loads under scenarios of land-use and management practices in a flat watershed. Water, Air, and Soil Pollution 154(1-4):271-293.

Dick, M.R., and J.W. Putnam. 1986. Conservation reserve and compliance: A paradox. Journal of Soil and Water Conservation 41(6):403-406.

Di Luzio, M., J.G. Arnold, and R. Srinivasan. 2004. Integration of SSURGO maps and soil parameters within a geographic information system and nonpoint source pollution model system. Journal of Soil and Water Conservation 59(4):123-133.
Dinnes, D.L., D.L. Karlen, D.B. Jaynes, T.C. Kasper, J.L. Hatfield, T.S. Colvin, and C.A. Cambardella. 2002 Nitrogen management strategies to reduce nitrate leaching in tile-drained Midwestern soils. Agronomy Journal 94:153-171.

Drinkwater, L.E., P. Wagoner, and M. Sarrantonio. 1998. Legume-based cropping systems have reduced carbon and nitrogen losses. Nature 396:262-265.

Duriancik, L.F., D. Bucks, J.P. Dobrowolski, T. Drewes, S.D. Eckles, L. Jolley, R.L. Kellogg, D. Lund, J.R. Makuch, M.P. O’Neill, C.A. Rewa, M.R.W., R. Parry, and M.A. Weltz. 2008. The first five years of the Conservation Effects Assessment Project. Journal of Soil and Water Conservation 63(6):185A-197A, doi:10.2489/jswc.63.6.185A

Flanagan, D.C., J.E. Gilley, and T.G. Franti. 2009. Water Erosion Prediction Project (WEPP): Development history, model capabilities, and future enhancements. Transactions of the American Society of the Agricultural and Biological Engineers 50(5):1603-1612.

Gassman, P.W., M. Reyes, C.H. Green, and J.G. Arnold 2007. The Soil and Water Assessment Tool: Historical development, applications, and future directions. Transactions of the American Society of Agricultural and Biological Engineers 50(4):1211-1250.

IDNR (Iowa Department of Natural Resources). 2008 Natural resources geographic information systems library. Iowa City, Iowa: Iowa Department of Natural Resources, Geological Survey. http://www.igsb.uiowa. edu/nrgislibx/.

ISU (Iowa State University). 2009. Environmental Mesonet: NWS COOP. Ames, IA: Department of Agronomy, Iowa State University. http://mesonet.agron.iastate. $\mathrm{edu} / \mathrm{COOP} /$.

Jha, M., P.W. Gassman, and J.G. Arnold. 2007. Water quality modeling for the Raccoon River Watershed using SWAT. Transactions of the American Society of Agricultural and Biological Engineers 50(2):479-493.

Jha, M., C.F. Wolter, P.W. Gassman, and K.E. Schilling 2010. Assessment of TMDL implementation strategies for nitrate impairment of the Raccoon River, Iowa Journal of Environmental Quality 39(4):1317-1327, doi:10.2134/jeq2009.0392.

Maringanti, C., I. Chaubey, and J. Popp. 2009. Development of a multiobjective optimization tool for the selection and placement of best management practices for nonpoint source pollution control. Water Resources Research 45: W06406, doi:10.1029/2008WR007094.

Moriasi, D.N., J.G. Arnold, M.W.Van Liew, R.L. Binger, R.D. Hermel, and T.Veith. 2007. Model evaluating guidelines for systematic quantification of accuracy in water simulations. Transactions of the American Society of Agricultural and Biological Engineers 50(3):885-900.
Nash, J.E., and J.V. Sutcliffe. 1970. River flow forecasting through conceptual models: Part 1. A discussion of principles. Journal of Hydrology 10(3):282-290.

Omernik, J.M. 1995. Ecoregions: A framework for environmental management. In Biological Assessment and Criteria: Tools for Water Resource Planning and Decision Making, ed. W. Davis and T. Simon, 49-62. Boca Raton, FL: Lewis Publishers.

Randall, G.W., D.R. Huggins, M.P. Russelle, D.J. Fuchs, W.W. Nelson, and J.L. Anderson. 1997. Nitrate losses through subsurface tile drainage in Conservation Reserve Program, alfalfa, and row crop systems. Journal of Environmental Quality 26:1240-1247.

Richardson, C.W., D.A. Bucks, and E.J. Sadler. 2008. The Conservation Effects Assessment Project benchmark watersheds: Synthesis of preliminary findings. Journal of Soil and Water Conservation 63(6):590-604, doi:10.2489/jswc.63.6.590.

Runkel, R.L., C.G. Crawford, and T.A. Cohn. 2004. Load Estimator (LOADEST): A FORTRAN program for estimating constituent loads in streams and rivers. USGS Techniques and Methods Book 4, Chapter A5. Reston, VA: US Geological Survey.

Santhi, C., J.G. Arnold, and J.R. Williams. 2001. Application of a watershed model to evaluate management effects on point and nonpoint source pollution. Transactions of the American Society of Agricultural and Biological Engineers 44(6):1559-1570.

Schilling, K.E. 2009. Investigating local variation in groundwater recharge along a topographic gradient, Walnut Creek, Iowa, USA. Hydrogeology Journal 17:397-407.

Schilling, K.E., T. Hubbard, J. Luzier, and J. Spooner. 2006 Walnut Creek Watershed Restoration and Water Quality Monitoring Project: Final Report. Iowa Geological Survey Technical Information Series 49. Iowa Department of Natural Resources, Iowa City, Iowa.

Schilling, K.E., M. Jha, Y.K. Zhang, P.W. Gassman, and C.F. Wolter. 2008a. Impact of land use and land cover change on the water balance of a large agricultural watershed: Historical effects and future directions. Water Resources Research 44:W00A09, doi:10.1029/2007WR006644.

Schilling, K.E., C.F. Wolter, D.E. Christiansen, D.J. Schnoebelen, and M. Jha. 2008b. Water quality improvement plan for Raccoon River, Iowa. TMDL Report. Watershed Improvement Section, Iowa Department of Natural Resources.

Schilling, K.E., and J. Spooner. 2006. Effects of watershedscale land use change on stream nitrate concentrations. Journal of Environmental Quality 35:2132-2145.

Schilling, K.E., and C.F. Wolter. 2009. Modeling nitratenitrogen load reduction strategies for the Des Moines 
River, Iowa using SWAT. Environmental Management 44:671-682, doi 10.1007/s00267-009-9364-y.

Schulte, L.A., M. Liebman, H. Asbjornsen, and T.R. Crow. 2006. Agroecosystem restoration through strategic integration of perennials. Journal of Soil and Water Conservation 61(6):164A.

Secchi, S., J. Tyndall, L.A. Schulte, and H. Asbjornsen. 2008. High crop prices and conservation: Raising the Stakes. Journal of Soil and Water Conservation 63(3):68A-73A, doi:10.2489/jswc.63.3.68A

Turner, R.E., and N.N. Rabalais. 1994. Coastal eutrophication near the Mississippi River delta. Nature 368:619-621.

USDA NASS. 2009. Agricultural Statistics Annual. http:// www.nass.usda.gov/Publications/Ag_Statistics/index.asp.

USDA NRCS (Natural Resources Conservation Service). 2008. Soil Survey Geographic (SSURGO) database. Washington, DC: USDA Natural Resources Conservation Service. http://www.soils.usda. gov/survey/geography/ssurgo/.

USEPA (US Environmental Protection Agency). 2003. National Section 303(d) List Fact Sheet.

USGS (US Geological Survey). 2008a. The national map seamless server. Reston, VA: US Geological Survey. http://seamless.usgs.gov/.

USGS. 2008b. National Hydrography Dataset. Reston, VA: US Geological Survey. http://nhd.usgs.gov/.

Walter, M.T., M. Dosskey, M. Khanna, J. Miller, M. Tomer, and J. Wiens. 2007. The science of targeting within landscapes and watersheds to improve conservation effectiveness. In Managing Agricultural Landscapes for Environmental Quality, Strengthening the Science Base, ed. M. Schnepf and C. Cox, 63-91. Ankeny, IA: Soil and Water Conservation Society.

White, M.J., D.E. Storm, P.R. Busteed, S.H. Stoodley, and S.J. Phillips. 2009. Evaluating nonpoint-source critical source area contributions at the watershed scale. Journal of Environmental Quality 38:1654-1663, doi:10/2134/jeq2008.0375. 